\title{
Natural Sciences
}

Citation: Gil-Guarín IC, VillabonaGonzález SL, Parra-García E, Echenique RO. Environmental factors driving phytoplankton biomass and diversity in a tropical reservoir. Rev. Acad. Colomb. Cienc. Ex. Fis. Nat. 44(171):423-436, abril-junio de 2020. doi: https://doi. org/10.18257/raccefyn.1052

Editor: Nelson Aranguren

*Corresponding autor: Isabel Cristina Gil Guarín; isabelcgg84@gmail.com

Received: October 29, 2019

Accepted: May 20, 2020

Published: June 30, 2020

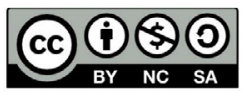

This is an open access article distributed under the terms of the Creative Commons Attribution License.
Original article

\section{Environmental factors driving phytoplankton biomass and diversity in a tropical reservoir}

\author{
Factores ambientales determinantes de la biomasa y la \\ diversidad del fitoplancton en un embalse tropical
}

\author{
- Isabel Cristina Gil-Guarín ${ }^{1, *}$, ๑ Silvia Lucía Villabona-González ${ }^{1}$, ¿ Edison Parra-García ${ }^{2}$, \\ (D) Ricardo O. Echenique ${ }^{3}$ \\ ${ }^{1}$ Grupo de Investigación en Limnología y Recursos Hídricos, Universidad Católica de Oriente, Rionegro, Colombia \\ ${ }^{2}$ Grupo de Investigación en Limnología Básica y Experimental y Biología y Taxonomía Marina, Instituto de \\ Biología, Universidad de Antioquia, Medellín, Colombia \\ ${ }^{3}$ Facultad de Ciencias Naturales y Museo, (UNLP)/CIC-BA, La Plata, Argentina
}

\begin{abstract}
We determined the spatial and temporal variation of phytoplankton biomass and diversity in 10 fortnightly sampling journeys verifying five sampling sites in El Peñol-Guatapé reservoir located in Antioquia, Colombia. In situ and ex situ physical and chemical variables were measured and phytoplankton samples were taken. Richness was dominated by Chlorophyta and biomass by Dinophyta. This variable was higher in the transition zone while in the riverine zone it showed average values, the lowest were registered in the lacustrine zone. Diversity was lower in the riverine zone, but it increased considerably in the transition zone and in the lacustrine zone where it showed similar values. At the vertical scale, biomass and diversity did not vary widely. Biomass showed a differential response to the effect of precipitation changes and water levels in the reservoir zones. Due to the low variability in environmental conditions, diversity was homogeneous time-wise. These results suggest that factors related to the hydrodynamic such as precipitation and water level resulting from the dam operation and inflow have a slight influence on the temporal variations of phytoplankton biomass and structure. There was a direct relationship between these attributes and physical variables such as turbidity and nutrients concentration at spatial scale while at the vertical scale, mixing patterns and the influence of the wind explained the absence of the vertical gradient of biomass and phytoplankton structure.
\end{abstract}

Keywords: Temporal and spatial variation; Physical chemical variables; Phytoplankton; Structure; Reservoir.

\section{Resumen}

Para determinar la variación espacial y temporal de la biomasa y la diversidad del fitoplancton, se realizaron diez campañas de monitoreo quincenales en cinco sitios ubicados en el embalse El Peñol-Guatapé en Antioquia, Colombia. Se midieron variables físicas y químicas y se tomaron muestras de fitoplancton. La riqueza fue dominada por Chlorophyta y la biomasa por Dinophyta, variable que fue mayor en la zona de transición, en tanto que en la zona riverina presentó valores medios y en la zona lacustre, los más bajos. La diversidad fue menor en la zona riverina, pero aumentó considerablemente en la zona de transición y en la zona lacustre, donde sus valores fueron semejantes. En el perfil vertical, la biomasa y la diversidad no variaron notablemente. La biomasa respondió de forma diferencial a las variaciones en la precipitación y el nivel del agua en las zonas del embalse. Como consecuencia de la baja variabilidad en las condiciones ambientales, la diversidad fue homogénea en el tiempo. Los resultados sugieren que factores relacionados con la hidrodinámica, tales como la precipitación y el nivel del agua resultantes de la operación del embalse y del caudal de entrada influyen levemente sobre la variación temporal de la biomasa y la diversidad del fitoplancton. Se registró una relación directa entre estos atributos y variables físicas 
como la turbidez y la concentración de nutrientes en la escala espacial, mientras que en la escala vertical los patrones de mezcla y la influencia del viento explicaron la inexistencia de gradientes verticales de la biomasa y la estructura fitoplanctónica.

Palabras clave: Variación temporal y espacial; Variables físicas y químicas; Fitoplancton; Estructura; Embalse.

\section{Introduction}

In tropical reservoirs, spatial and temporal variations of some factors as temperature, light, dissolved oxygen, $\mathrm{pH}$, electric conductivity, and nutrients determine changes in phytoplankton composition, biomass, and diversity (Padisák, et al., 2010; Stomp, et al., 2011). Likewise, important elements of hydrodynamic, such as water level fluctuations, hydroelectric generation, and precipitation are some of the main factors that control phytoplankton biomass and diversity in these systems (Mac Donagh, et al., 2009). These factors generate pulses of suspended material and nutrients producing a reorganization in terms of phytoplankton taxa relative biomass (Calijuri, 1999). Besides controlling light and nutrients, these factors also affect the maintenance or not of phytoplankton in the water column (Reynolds, 2006; Bernhardt, et al., 2008). In the particular case of reservoirs for energy generation, hydrological features vary because of the operation of hydroelectric power plants. Consequently, variations of inflow and outflow, water level, and water residence time directly affect physical, chemical, and biological conditions. The riverine zone receives a high nutrient input but light attenuation, turbulence, and general lotic conditions reduce primary production. As sedimentation and light availability increase along the longitudinal gradient, phytoplankton reaches high biomass in the intermediate zone. Finally, the lacustrine zone characterizes by nutrient limitations and phytoplankton biomass reduction (Thornton, et al., 1990).

Factors such as morphometric characteristics, thermal stratification, geographic location, and residence time may influence the boundaries of these reservoir regions. Thus, a reservoir might become a fluvial system when residence time is lower than 30 days or be totally lacustrine when this time is higher than 50 days (Tundisi \& Straskraba, 1999). In this sense, species diversity also varies depending on this complex range of factors (Wetzel, 1993).

There have been numerous studies employing phytoplankton as an indicator of changes in ecological conditions of different reservoirs (Figueredo \& Giani, 2001; NascimientoMoura, et al., 2007; Lira, et al., 2011; Marti, et al., 2016; Wojciechowski, et al., 2017), due to its capacity to respond quickly (days and hours) and differentially to these changes.

Given the great number of species that conform phytoplankton and that, potentially, some of them can dominate and co-dominate in a system (Reynolds, 1997; Reynolds, et al., 2002), it is necessary to simplify the analysis by using indices that summarize the structure of this community. Margalef (1994) and Connell (1978) argued that systems subject to periodic changes of environmental variables or anthropogenic tensions present higher diversity values because these conditions favor the coexistence of taxa with different ranges against the available resources (Calijuri, et al., 2002). On the other hand, more stable systems characterize by expressing lower values of specific richness and higher values of dominance due to competitive exclusion in these types of disturbed systems (Figueredo \& Giani, 2001).

In Colombia, phytoplankton analysis in reservoirs has focused on its composition and structure estimated from numerical abundance (Ramírez, 1986; Duque \& Donato, 1988; Donato, 2001; Aguirre-Ramírez, et al., 2007; Palacio-Baena, et al., 2013; RodríguezZambrano, et al., 2014), except for the work by Hernández-Atilano, et al. (2012), León-López, et al. (2012); Ospina-Calle (2013), López-Muñoz, et al. (2015; 2016), who considered its biomass. Some studies conducted in El Peñol-Guatapé reservoir have centered on the variability of its physical and chemical attributes, as well as its biological features (Uribe \& Roldán, 1975; Roldán, 1978, 1982; Björk \& Gelin, 1980; Palacio- 
Baena \& Plazas, 1998; Ramírez, 1989; Aguirre-Ramírez, et al., 2007), but none of them has considered the evaluation of the phytoplankton structure based on its biomass. In this context, the aim of this study was to determine the spatial and temporal variation of the biomass and diversity of phytoplankton in El Peñol-Guatapé reservoir and its relationship with some environmental variables. The study question was: $¿$ What are the factors that mainly affect the spatial (horizontal and vertical) and temporal variation of the biomass and the specific diversity of phytoplankton in the El Peñol-Guatapé reservoir? At spatial horizontal scale, our hypothesis was that if the variation of phytoplankton biomass and diversity were influenced by nutrient concentration and turbidity, in the riverine zone (SS1) the biomass would be higher and the diversity lower. At spatial vertical scale, we assumed that if the variation of these attributes between depths was due to the light availability, it could be expected that the biomass would be higher and the diversity would decreased in the subsurface.

At the temporal scale, we hypothesized that if the variations of the phytoplankton biomass and diversity answered to precipitation and water level fluctuations, they would decrease during high water level seasons.

\section{Materials and methods}

\section{Study area}

El Peñol-Guatapé reservoir is located at 1887.5 masl in the eastern Antioquia-Colombia $\left(6^{\circ} 13\right.$ '20'N - 75'10'11' W) within the jurisdiction of El Peñol, Guatapé and, San Rafael municipalities (Figure 1). At its maximum height, it has an area of 6253.6 has, a capacity

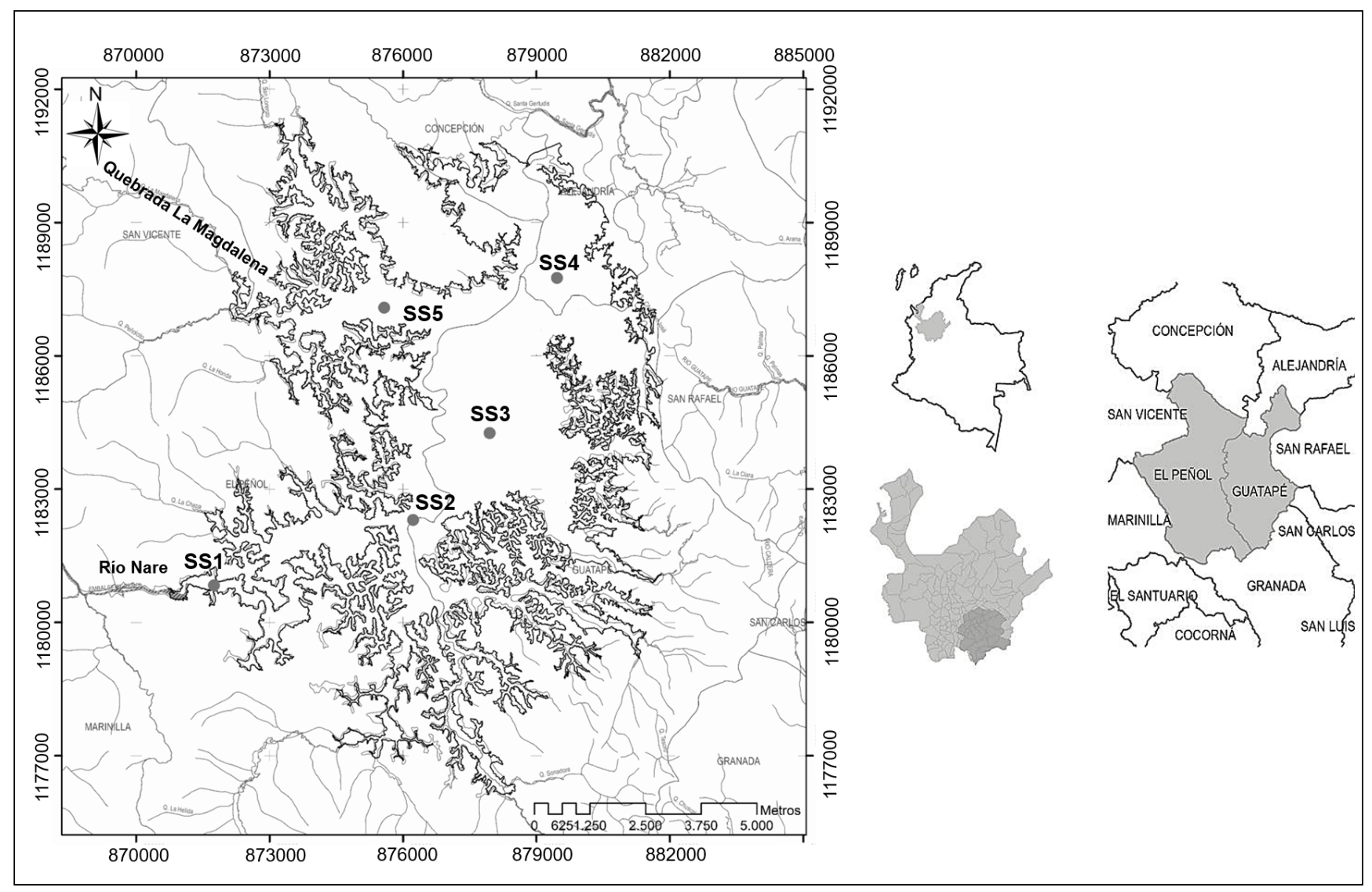

Figure 1. Geographic location of El Peñol-Guatapé reservoir and of the sampling sites (SS1: riverine zone, SS2 and SS3: transition zone, SS4 and SS5: lacustrine zone) 
of 1.240 million $\mathrm{m}^{3}$, maximum deep of $52 \mathrm{~m}$, and an average residence time of 82 days (Bedoya-Cardona, 2017). Its main tributary is the Nare River, which contributes an average annual flow of $51.8 \mathrm{~m}^{3} / \mathrm{s}$. It is mainly used for hydroelectric generation, tourism, and artisanal fishing. Its catchment area has been subjected to industrial, agricultural, livestock, and mining developments resulting in the deterioration of the quality of water (Cuéllar-Márquez, 2009).

We conducted biweekly field surveys (FS1 to FS10) from August to December 2014 in five sampling sites (riverine zone: SS1, transition zone: SS2 and SS3, and lacustrine zone: SS4 and SS5) (Figure 1). Field surveys were carried out in four periods: Dry season (August), transition to the rainy season (September), rainy season (October and November), and transition to the dry season (December) (Figure 2). Water transparency was determined by measuring Secchi disk extinction depth while water temperature, electric conductivity, dissolved oxygen, turbidity, $\mathrm{pH}$, and chlorophyll- $a$ were measured in situ using a CTD profiler. Based on temperature profiles, we estimated the Thermocline Strength Index (TSI). To quantify total nitrogen $(\mathrm{TN})$, organic nitrogen $(\mathrm{ON})$, sulfates $\left(\mathrm{SO}_{4}\right)$, carbon dioxide $\left(\mathrm{CO}_{2}\right)$, total organic carbon (TOC) concentrations, and turbidity, water samples were collected with a Schindler bottle at $100 \%$ and $1 \%$ incident light. Nutrients and sulfates concentrations were estimated using ionic chromatography, $\mathrm{CO}_{2}$ by the titrimetric method, and COT and turbidity by nephelometry. The climatological information, as well as inflow and outflow data were provided by Empresas Públicas de Medellín. For the qualitative analysis of phytoplankton, samples were collected with Schindler bottle at $100 \%$ and at $1 \% \mathrm{E}_{\mathrm{o}}$ incident light and then preserved with acetic Lugol's solution (Ramírez, 2000). For the quantitative analysis of phytoplankton we followed Utermöhl's (1958) method using an Olympus inverted microscope, considering the estimated biovolume per taxa, and assuming that organisms and water had the same density, biomass was reported in $\mathrm{mg} / \mathrm{L}$ (Edler, 1979; Wetzel \& Likens, 1991).

The Olmstead-Tukey association test was applied to classify the phytoplankton species as dominant, constant, occasional, and rare (Sokal \& Rohlf, 1981). To analyze the phytoplankton community structure, we calculated the diversity numbers developed by Hill (1973): q0 (species richness), q1 (diversity of common species), and q2 (diversity of dominant species). We used a three-way factorial ANOVA test or Kruskal-Wallis test when the assumptions of parametric statistics were not fulfilled to determine the statistical differences in biomass, richness, and diversity among sampling campaigns, sampling sites,

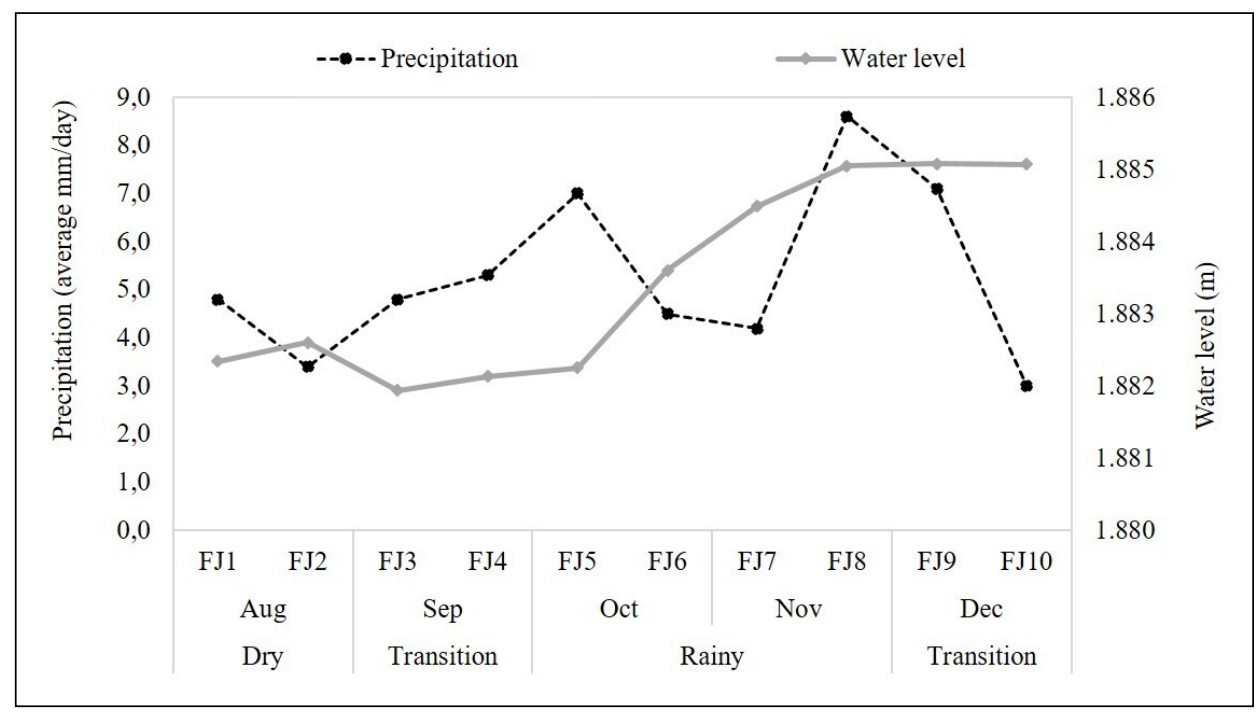

Figure 2. Precipitation and water level in El Peñol-Guatape reservoir (August - December 2014) 
and depths. If there was a significant difference between these factors, we used post-hoc, Tukey, or Mann-Whitney tests. Biomass values were transformed to square root and species richness was normalized using $X^{2}$ (Guisande-González, et al., 2011). We used multiple correlations to evaluate the association between biomass and diversity indices grouped per zone with precipitation and water level. For these analyses, we used the R wizard version 2.3 (Guisande-González, et al., 2014). We performed a Generalized Canonical Discriminant Analysis on the biomass of the dominant, constant, occasional, and rare taxa, as well as on the physical and chemical variables. The scores and the canonical vectors were calculated to graph the most important canonical discriminant functions in terms of explained variance, thus allowing the simplest interpretation in the canonical space of differentiation between the algal biomass and the environmental matrix (Friendly, 2007).

\section{Results}

Nare River flow (inflow) was higher during the rainy season in September, October, and November and lower in the dry season (August) and during the transition to the dry one (December). Outflow was higher during the transition to the rainy season (September) and the rainy season in October and November, and lower in the transition to the dry season (December). At the end of November, almost when we were finishing the study, the water level had increased 5 meters approximately (Figure 2). Consequently, with the variations of inflow and outflow, residence time was higher in December.

We identified 67 taxa belonging to eight algal divisions. Chlorophyta contributed the most to richness with 25 taxa, which meant $37.3 \%$ of the total. We also identified 14 taxa belonging to Cyanobacteria, nine to Charophyta and Euglenophyta (13.04\%, respectively), five to Dinophyta (7.5\%), two to Cryptophyta and Ochrophyta (2.9\%, respectively), and one to Bacillariophyta (1.4\%). Dinophyta contributed with $55 \%$ of the total biomass followed by Chlorophyta with $20 \%$ and Cyanobacteria with $11 \%$ while other divisions reached less than $6 \%$. According to the Olmstead-Tukey association test, 12 taxa were dominant, nine were constant, and 46 were rare. (Table 1).

Phytoplankton total biomass ranged from 0.46 to $56.6 \mathrm{mg} / \mathrm{L}(\bar{x} 10.6 \mathrm{mg} / \mathrm{L})$. The variance analysis (ANOVA) and the Tukey test (Figure 3) showed significant differences for this variable at the temporal scale determined by its increase during those periods with less rainfall (SJ1 $\bar{x}=14.1 \mathrm{mg} / \mathrm{L})$ and the transition to dry season (SJ9 y SJ10 $\bar{x}=13.6$ and $\bar{x}=22.6 \mathrm{mg} / \mathrm{L}$ ) and its decease during the periods with less rainfall and high outflow (FS2 and FS3: $\bar{x}=5.70$ and $\bar{x}=5.51 \mathrm{mg} / \mathrm{L})$.

Table 1. Dominant taxa registered in El Peñol-Guatapé

\begin{tabular}{lcccc}
\hline Taxa & Frequence & \% Frequence & Biomass (mg/L) & Relative biomass (\%) \\
\hline Botryococcus braunii & 73 & 82.02 & 139.97 & 14.84 \\
Ceratium furcoides & 63 & 70.79 & 222.38 & 23.57 \\
Chroococcus minutus & 89 & 100.00 & 36.65 & 3.89 \\
\hline Cryptomonas spp. & 61 & 68.54 & 45.31 & 4.80 \\
Cyclotella spp. & 79 & 88.76 & 53.66 & 5.69 \\
Microcystis wesenbergii & 34 & 38.20 & 20.97 & 2.22 \\
Oocystis cf. lacustris & 87 & 97.75 & 43.24 & 4.58 \\
Oscillatoria limosa & 50 & 56.18 & 37.11 & 3.93 \\
Parvodinium spp. & 85 & 95.51 & 147.50 & 15.64 \\
Peridiniales & 82 & 92.13 & 64.73 & 6.86 \\
Peridinium gatunense & 64 & 71.91 & 79.67 & 8.45 \\
Staurastrum rotula & 52 & 58.43 & 14.44 & 1.53 \\
\hline
\end{tabular}


The post hoc Mann-Whitney test showed that in the transition zone (SS2 y SS3), phytoplankton biomass reached significantly higher values, with a median of 12.19 and $14.31 \mathrm{mg} / \mathrm{L}$, respectively. In the riverine (SS1) and lacustrine zones (SS4 and SS5), significantly lower values were estimated (medians: $3.47,5.22$, and $4.64 \mathrm{mg} / \mathrm{L}$, respectively).

At the vertical scale, no significant differences were registered (Figure 3). Diversity of order 0,1 and 2 showed no statistically significant differences among field surveys, nor between depths and among interactions (Figure 3).

Diversity of order 0 ranged from 9 to $23(\bar{x}=17)$. ANOVA showed statistically significant differences among sampling sites because it was higher in the transition zone while it was lower in the lacustrine one (Figure 3). Considering common taxa and their contribution to biomass for estimating diversity of order 1, q1 exhibited significant differences among sampling sites (Figure 3) because the transition and lacustrine zones had a diversity mean value equal to that of a virtual community of 5.18 taxa with the same biomass. It is possible to say that transition and lacustrine zones were 1.73 times more diverse than the riverine zone considering mean values. Regarding the diversity of order 2 (q2), again the riverine zone was the less diverse sampling site (Figure 3). The ratio of the depth of the euphotic zone (Zeu)/mix zone, ( $\mathrm{Zmix})$ ) exhibited a mean value $\geq 1$ except in one case suggesting that organisms are active in a zone where light is available for phytoplankton growth. Table 2 shows the minimum and maximum values, the arithmetic mean, and the standard deviation of variables used in the discriminant analysis. Water temperature did not register important fluctuations $(\mathrm{CV}=4.2 \%)$ with values ranging from 21.4 to $25.3^{\circ} \mathrm{C}$ and a mean value of $23.3^{\circ} \mathrm{C}$. At the vertical scale, dissolved oxygen concentration had a CV=41.5\% with mean values of $2.9 \mathrm{mg} / \mathrm{L}$ at $1 \%$ Eo and $5.9 \mathrm{mg} / \mathrm{L}$ at $100 \%$ Eo. Among sampling sites, the highest concentration occurred at the riverine zone with most values over or close to $6 \mathrm{mg} / \mathrm{L}$. $\mathrm{CO}_{2}$ concentration showed a vertical pattern inverse to that of dissolved oxygen with the highest concentrations at $1 \%$ Eo $(5.1 \mathrm{mg} / \mathrm{L})$ and the lowest at $100 \%(2.5 \mathrm{mg} / \mathrm{L})$ while at the spatial and temporal scales, concentrations

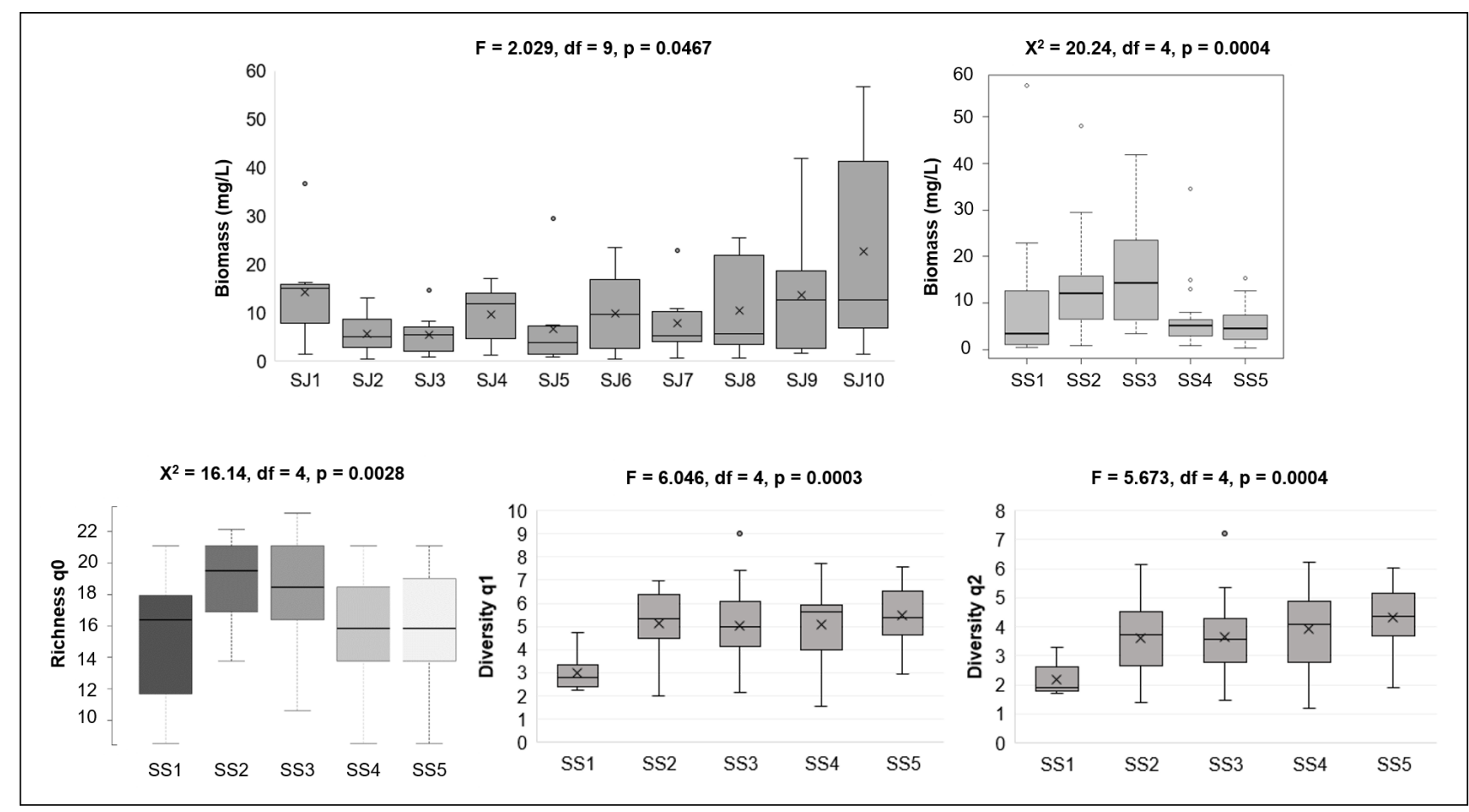

Figure 3. Phytoplankton biomass and diversity. Boxplots showing phytoplankton biomass, richness (q0), and diversity (q1 and q2) during 10 sampling journeys at five sites, SS1, SS2, SS3, SS4 and SS5, in El Peñol-Guatapé Reservoir (August to December 2014) 
Table 2. Values of physical and chemical variables in the photic zone, arithmetic mean, Standard Deviation (SD) and Coefficient of Variation (CV, \%). El Peñol-Guatapé Reservoir (August - December 2014)

\begin{tabular}{|c|c|c|c|c|c|c|c|c|c|c|c|c|}
\hline \multirow{2}{*}{$\begin{array}{l}\text { Variables and } \\
\text { measurement units }\end{array}$} & \multicolumn{4}{|c|}{ Riverine Zone } & \multicolumn{4}{|c|}{ Transition Zone } & \multicolumn{4}{|c|}{ Lacustrine Zone } \\
\hline & $\bar{x}$ & Max. & Min. & CV $(\%)$ & $\bar{x}$ & Max. & Min. & CV $(\%)$ & $\bar{x}$ & Max. & Min. & CV $(\%)$ \\
\hline $\begin{array}{l}\text { Ammoniacal nitrogen } \\
(\mathrm{mg} \mathrm{N}-\mathrm{NH} 3 / \mathrm{L})\end{array}$ & 0.04 & 0.10 & 0.01 & 89.75 & 0.12 & 0.49 & 0.01 & 114.98 & 0.11 & 0.37 & 0.01 & 98.22 \\
\hline Nitrates mg (N-NO3-/L) & 0.20 & 0.56 & 0.03 & 89.12 & 0.86 & 2.63 & 0.07 & 97.84 & 0.41 & 2.30 & 0.02 & 141.51 \\
\hline Total nitrogen (mg N/L) & 0.32 & 0.80 & 0.18 & 55.16 & 0.52 & 1.18 & 0.03 & 54.24 & 0.37 & 0.77 & 0.02 & 52.17 \\
\hline Organic nitrogen $(\mathrm{mg} / \mathrm{L})$ & 0.26 & 0.59 & 0.10 & 54.80 & 0.26 & 0.90 & 0.00 & 82.45 & 0.23 & 0.62 & 0.00 & 57.00 \\
\hline Sulfates (mgSO4/L) & 1.96 & 2.57 & 1.59 & 20.51 & 2.08 & 3.64 & 1.37 & 24.96 & 1.74 & 3.34 & 1.28 & 25.04 \\
\hline Carbon dioxide (mgCO2/L) & 1.95 & 4.00 & 0.00 & 56.72 & 3.86 & 9.70 & 0.85 & 51.04 & 3.91 & 8.07 & 1.70 & 48.18 \\
\hline $\begin{array}{l}\text { Total organic carbon } \\
\text { (TOCmg C/L) }\end{array}$ & 3.80 & 5.60 & 1.37 & 29.00 & 3.23 & 7.06 & 1.00 & 30.42 & 2.72 & 3.62 & 1.00 & 22.85 \\
\hline Chlorophyll a ( $\mu \mathrm{g} / \mathrm{L})$ & 3.83 & 6.90 & 1.06 & 49.22 & 0.82 & 2.85 & 0.05 & 71.74 & 1.87 & 52.41 & 0.04 & 444.98 \\
\hline Turbidity (NTU) & 10.72 & 23.85 & 4.02 & 66.89 & 1.82 & 5.69 & 0.97 & 48.59 & 2.00 & 7.39 & 0.71 & 80.00 \\
\hline Temperature $\left({ }^{\circ} \mathrm{C}\right)$ & 24.28 & 25.31 & 22.98 & 2.85 & 23.23 & 24.87 & 21.60 & 4.28 & 23.07 & 24.63 & 21.38 & 3.80 \\
\hline Oxygen saturation ( \%) & 83.63 & 100.61 & 25.31 & 26.16 & 50.42 & 80.11 & 10.96 & 50.24 & 58.24 & 78.67 & 7.72 & 33.80 \\
\hline Dissolved oxygen (mg O2/L) & 6.89 & 8.28 & 5.54 & 13.95 & 4.15 & 6.68 & 0.67 & 48.08 & 4.44 & 6.57 & 0.68 & 35.28 \\
\hline pH (units) & 9.01 & 9.79 & 7.67 & 6.40 & 7.13 & 8.27 & 6.50 & 7.03 & 7.06 & 7.77 & 6.49 & 4.88 \\
\hline Conductivity ( $\mu \mathrm{S} / \mathrm{cm})$ & 54.02 & 60.24 & 47.63 & 8.37 & 52.12 & 73.35 & 43.09 & 14.65 & 44.72 & 70.19 & 35.93 & 15.67 \\
\hline Transparency (m) & 1.90 & 3.00 & 1.13 & 34.56 & 4.75 & 5.90 & 3.47 & 14.22 & 5.40 & 7.84 & 3.75 & 19.11 \\
\hline Biomass (mg/L) & 11.00 & 56.63 & 0.46 & 159.42 & 14.78 & 48.02 & 0.86 & 72.69 & 6.21 & 34.54 & 0.36 & 97.62 \\
\hline Richness (q0) & 15.00 & 21.00 & 9.00 & 28.89 & 19.00 & 23.00 & 11.00 & 14.26 & 16.00 & 21.00 & 9.00 & 19.60 \\
\hline q1 & 2.98 & 4.71 & 2.27 & 27.01 & 5.09 & 8.99 & 1.99 & 30.08 & 5.28 & 7.72 & 1.55 & 24.12 \\
\hline q2 & 2.18 & 3.30 & 1.70 & 25.66 & 3.63 & 7.22 & 1.40 & 36.24 & 4.12 & 6.21 & 1.19 & 27.83 \\
\hline
\end{tabular}

*Organic nitrogen is the sum of various forms of nitrogen.

were very fluctuating $(\mathrm{CV}=52.8 \%)$. Electric conductivity varied between 35.9 and 75.3 $\mu \mathrm{S} / \mathrm{cm}$ with a mean value of $49.1 \pm 8.04 \mu \mathrm{S} / \mathrm{cm}$ and a slight variation $(\mathrm{CV}=16.4 \%)$. At the spatial scale, the riverine zone showed the highest values for this variable (mean value: $54 \mu \mathrm{S} / \mathrm{cm}$ ). pH ranged between 6.5 and 9.8 units with a mean value of 7.3 and little variation $(\mathrm{CV}=10.3 \%)$ with the highest values in the riverine zone where the media value was over 9 units. At the vertical scale, $\mathrm{pH}$ was higher at $100 \%$ (7.7 units of $\mathrm{pH})$. Total nitrogen concentration varied between 0,02 and $1,18 \mathrm{mg} / \mathrm{L}$ with a mean value of $0,43 \pm 0,25$ $\mathrm{mg} / \mathrm{L}$ and high variation $(\mathrm{CV}=57,25 \%)$. According to the Kruskal-Wallis test, dissolved oxygen concentration, $\mathrm{pH}$, and electric conductivity showed significant differences at the spatial scale $(p<0.05)$. Except for conductivity, the other variables registered significant differences at the vertical scale. These variables showed no difference between sampling journeys except for total nitrogen that was different in all the evaluated factors. TSI values were in all cases lower than $1{ }^{\circ} \mathrm{C} / \mathrm{m}$ indicating thermocline did not occur and, consequently, there was vertical homogeneity.

We found a negative correlation between precipitation and biomass in the lacustrine zone; however, the correlation coefficient was low $(\mathrm{r}=-0,33$; $\mathrm{p}=0,04)$ while the increase of water level showed a positive correlation with biomass in the riverine $(\mathrm{r}=0,65 ; \mathrm{p}=0,04)$ and transition $(\mathrm{r}=0,35 ; \mathrm{p}=0,03)$ zones where it also showed a slight association with dominant species diversity $(\mathrm{r}=0,36 ; \mathrm{p}=0,02)$. We found no significant correlations of precipitation and water level with the community structure. 

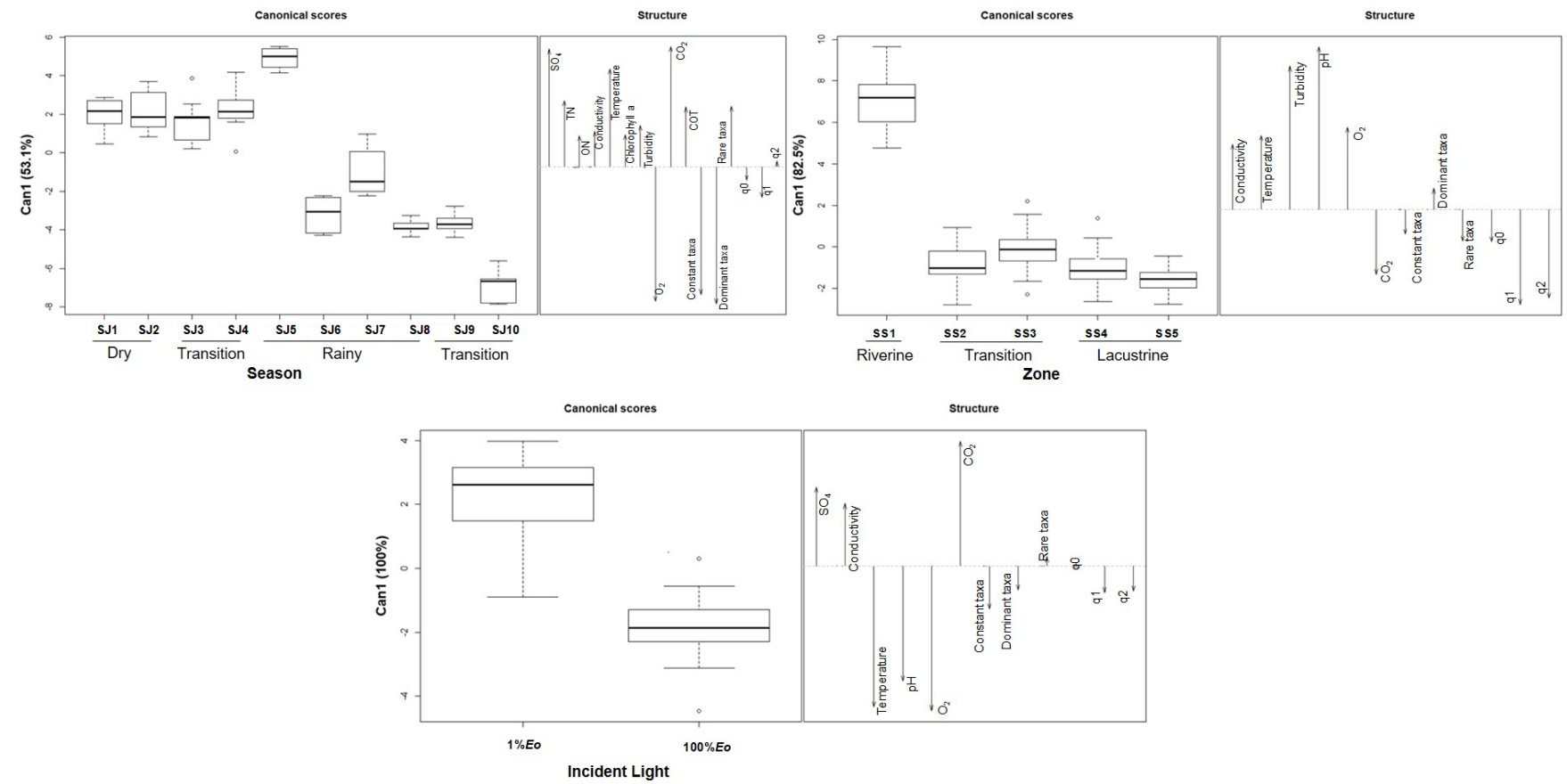

Figure 4. First canonical axis of the Generalized Discriminant Canonical Analysis for phytoplankton biomass and diversity and environmental variables. SO4: Sulfates $(\mathrm{mg} / \mathrm{L})$. TN: Total nitrogen $(\mathrm{mg} / \mathrm{L})$. Organic nitrogen $(\mathrm{mg} / \mathrm{L})$. Temperature $\left({ }^{\circ} \mathrm{C}\right)$. Chlorophyll $a(\mu \mathrm{g} / \mathrm{L})$. Turbidity $(\mathrm{NTU})$. O2-Dissolved oxygen $(\mathrm{mg} / \mathrm{L})$. Carbon Dioxide $(\mathrm{mg} / \mathrm{L})$. Total organic carbon $(\mathrm{mg} / \mathrm{L})$. Constant taxa-Constant taxa biomass $(\mathrm{mg} / \mathrm{ml})$. Dominant Taxa-Dominant taxa biomass (mg/ml). Rare taxa-Rare taxa biomass (mg/ml). q0: Richness. q1: Order 1 diversity. q2: Order 2 diversity

At the temporal scale, the discriminant analysis showed $92.3 \%$ of cases correctly identified and a cross-validation percentage of $47.7 \%$. The first axis explained $53.13 \%$ of the variance and showed that those sampling journeys carried out during the period of lower precipitations, low water level, and high water outflow (FS1 to FS5) were characterized by the increase of sulfate, total nitrogen, and $\mathrm{CO}_{2}$ concentrations, temperature, and rare taxa biomass. The survey carried out during the transition to the dry season (FS10) was discriminated against by the increase of both oxygen and the biomass of dominant and constant taxa (Figure 4). The ordination per sampling sites showed that in $70.8 \%$ of cases the identification was correct and cross-validation was 50.5\%. Physical and chemical variables, as well as the diversity of orders 1 and 2, were those that discriminated the most. The first axis explained $82.5 \%$ and allowed the discrimination of the riverine zone (SS1) with higher values of electric conductivity, temperature, turbidity, $\mathrm{pH}$, and dissolved oxygen. The discrimination of the transition and lacustrine zones was due to by the increase of $\mathrm{CO}_{2}$ concentration and the higher values of order 1 and 2 diversity (Figure 4). At the vertical scale, in the first axis, the discriminant analysis explained $100 \%$ of variability while $96.6 \%$ of cases were correctly identified through cross-validation. Axis 1 showed a vertical variation differentiating between samples taken at $1 \%$ Eo in function of abiotic variables as temperature, $\mathrm{pH}$, and dissolved oxygen showing a tendency to differentiate by the biomass of constant taxa. Samples taken at $1 \%$ Eo were differentiated by high electric conductivity values, sulfates, and carbon dioxide while subsurface showed warmer and oxygenated waters with higher $\mathrm{pH}$ (Figure 4).

\section{Discussion}

The phytoplankton community's taxonomic richness was a little over that recorded in previous studies (Ramírez, 1986; Aguirre-Ramirez, et al., 2007). As reported by Ramírez (1986) and Aguirre-Ramírez (2007), Chlorophyta was the group which contributed the most to taxonomic richness. 
Our results suggest that the spatial and temporal variation of the biomass and the structure of the phytoplankton community in El Peñol Guatapé reservoir were determined more by the horizontal gradient in function of biotic and abiotic variables allowing for the differentiation of the riverine zone by electrical conductivity, $\mathrm{pH}$, temperature, dissolved oxygen, and turbidity as a consequence of the entrance of Nare River, the low residence time, and phytoplankton production processes. Other factors such as higher transparency and the decrease of nutrient concentrations in the transition and lacustrine zones also influenced the process of spatial compartmentalization proposed by Thornton, et al. (1990). Phytoplankton biomass and diversity exhibited a longitudinal pattern corresponding to this gradient. The riverine zone, directly influenced by the Nare River, is shallower (total depth of $5.9 \mathrm{~m}$ on average), more turbid (average=10.7 NTU), and turbulent, as well as exposed to a higher nutrients input derived from agricultural activities and industrial and urbanism projects in the basin, showing lower average biomass than that recorded in the transition zone where turbidity was lower (1.5 NTU) and the nutrient concentration is average according to Thornton, et al. (1990), although this condition was not recorded due to the assimilation by phytoplankton and other physical and chemical processes. These differences also affected phytoplankton diversity. In the riverine zone, the contribution of few organisms to the total biomass responded to the mixture of the water column, the high turbulence, and, in general, its capability of developing in a wide variety of conditions. In contrast, in the transition zone, the sedimentation of solids and the subsequent increase in light availability, as well as the decrease of turbulence and higher wind influence, favored greater biomass. However, given that several taxa contributed proportionally to the total biomass, the diversity was higher. Both the transition and lacustrine zones showed a slight tendency to differentiate based on the constant and rare taxa biomass. The presence of these groups of organisms in these zones is important because they have specific habitat requirements, their limits of tolerance are narrower, and their competing capacity lower, so better environmental conditions, high transparency, and a lower concentration of nutrients in these areas may have favored its development. It is worth mentioning the possible influence of the wind in these sampling sites, a factor that, given the changes of direction, causes turbulence in the superficial layers mixing the cells and displacing organisms in different depths resulting in the appearance of different phytoplankton taxa (Webster, 1990). In this sense, it is very important to consider the analysis scale because the variation in abiotic conditions occurs faster than the ability of phytoplankton to respond to environmental changes making it difficult to observe clear patterns in its dynamics. Therefore, more attention should be given to scale definition when sampling and designing studies in reservoirs.

Vertical variation of phytoplankton biomass and diversity are influenced by a synergy between the mixing regime and nutrients, especially nitrate, as well as hydrology, turbulence, wind action, temperature and light (Melo \& Huszar, 2000, Bouvy, et al., 2003, Nascimiento-Moura, et al., 2007, Costa et al., 2006, 2009, Marti et al., 2016). Nevertheless, in this study neither the biomass nor the diversity showed dependence on biotic factors, probably due to the occurrence of mixing and transport processes, favored by inflow and outflow and wind, which could cause the homogeneous distribution of phytoplankton by keeping organisms in suspension by means of advective transport processes, important mechanisms of horizontal transport of particles. A very different result from those found in other studies (Webster, 1990, Ramírez, et al., 2000, Lira, et al., 2014, Soares-Vieria, et al., 2015, López-Muñoz, 2015), even in this same reservoir (AguirreRamírez, et al., 2007). In this study, along the photic zone, as it was reported by SoaresVieria, et al. (2015), it was observed a gradient in the expression of temperature, $\mathrm{pH}$ and dissolved oxygen related to photosynthetic activity, a process that allows $\mathrm{CO}_{2}$ removal, oxygen production and therefore $\mathrm{pH}$ increase.

Our results show that factors related to hydrodynamic such as precipitation and water level variations resulting from the operation of hydroelectric power plants and inflow have a slight influence on the temporal variations of phytoplankton structure, although 
they are important factors that can drive spatial compartmentalization of phytoplankton in reservoirs (Mac Donagh, et al., 2009; Soares, et al., 2008; Tundisi, et al., 1999) because water body movements affect the availability of resources for phytoplankton (Tundisi, et al., 2008). According to Hooper, et al. (2005), Soares, et al. (2008), and Mac Donagh, et al. (2009), successful colonization by rare organisms can be influenced by the availability of resources, as well as disturbance conditions associated with high hydrological dynamics, for which their biomass and frequency are below the average as it was reported by Barbiero, et al. (1999). In this sense, Calijuri, et al. (2002) highlighted the influence of the hydraulic regime on determinant environmental factors for the development of phytoplankton. Although rare taxa did not contribute significantly to phytoplankton dynamics, they are very important because of their influence on community structure. Their importance lies in their participation in resource assimilation, which implies that in a community where they are significant, the use of resources is more efficient (Loreau \& Hector, 2001). With regard to the temporal dynamics, the discriminant analysis showed that the concentration of sulfates, total nitrogen, carbon dioxide, temperature, and turbidity associated with the periods of highest hydroelectric generation and the dry season (August, September, and some days at the beginning of October). In December, due to the decrease in rainfall and the reduction of Nare River inflow, the stability of water level, the reduction of outflow for hydroelectric generation, and the increase of residence time differentiated by the increment of dominant and constant taxa biomass and high dissolved oxygen concentration as evidence of the high photosynthetic activity occurring during these campaigns. Correspondingly, the lower concentrations of $\mathrm{CO}_{2}$ recorded resulted from high levels of production (Balmer \& Downing, 2011). The increase of dominant and constant taxa biomass during these periods responds to the fact that they are generalists with a wide range of tolerance, which represents advantages in the use of resources and greater spatial-temporal dispersion in the system. Conversely, diversity did not show important variations probably due to: i) a constant supply of nutrients to the reservoir through its tributaries, especially Nare River and La Magdalena ravine; ii) the stability and magnitude of the temperature, whose values are optimal (average: $23.3{ }^{\circ} \mathrm{C}$ ) and favor phytoplankton growth rates and high nutrientconversion rate, therefore increasing the productivity of the reservoir (Roldán-Pérez \& Ramírez, 2008), and iii) the long hydraulic retention time favoring the stability of environmental conditions.

\section{Conclusions}

The hypothesis related to the spatial variation was partially demonstrated as in the riverine zone, the most turbid site with the highest concentration of nutrients, biomass was lower than the value registered in the transition zone where transparency was greater and the concentration of nutrients medium. The biomass found in the riverine zone was lower than the one estimated in the lacustrine zone because in the former the intense flow and turbidity possibly acted disturbing the phytoplankton frequently.

Richness and diversity had a relatively similar pattern, as they were lower in the riverine zone but increased considerably in the transition and lacustrine zones where their values were very similar. We can conclude that the postulated vertical gradient of biomass and diversity did not occur probably due to mixing patterns and wind influence, which was further proved by the fact that TSI thermocline was not present and the Zeu/Zmix ratio the photic zone was included in the mix zone.

At the temporal scale, the results also partially supported the hypothesis given that, although during the study period the phytoplankton biomass did not present a pattern associated with precipitation or water level, it did show differential responses in the longitudinal gradient. Phytoplankton diversity did not show strong variation among sampling periods probably because nutrient inputs are constant in the reservoir as is the temperature. Additionally, the residence time was generally high and the phytoplankton 
community was formed by organisms characterized by effective responses to environmental conditions in the system, such as Botryococcus braunii, Ceratium furcoides, Chroococcus minutus, Cryptomonas sp2 and Parvodinium sp.

\section{Acknowledgements}

The study was part of a research project financed by Empresas Públicas de Medellín (EPM) through a Masters fellowship granted to the first author and the support for some of the research activities. We thank John Jairo Ramírez for reviewing the base document, Célia L. Sant'Anna for facilitating the taxonomic work, and speciallly María Isabel Ríos Pulgarín for her help, and Sara Cadavid and Claudia Bedoya for their support during the sampling campaigns.

\section{Conflicts of interest}

The authors declare no conflict of interest.

\section{Author contribution}

ICGG, collected and did qualitative and quantitative analysis of samples, as well as data base construction, data analysis, literature review and writing of different components of the paper; SLVG, revised the treatment given to data, gave support with discriminant analysis, description of results and discussion, as well as construction of figures; EAPG, gave support with analysis of results and discussion; ROE, gave support with phytoplankton taxonomy, description of results and a general revision of different components of the paper.

\section{References}

Aguirre-Ramírez, N. J., Palacio-Baena, J., Ramírez, J. J. (2007). Características limnológicas del embalse El Peñol-Guatapé, Colombia. Revista de Ingenierías Universidad de Medellín. 6 (10): 53-66. https://revistas.udem.edu.co/index.php/ingenierias/article/view/223

Balmer, M.B. \& Downing, J. (2011). Carbon dioxide concentrations in eutrophic lakes: Under saturation implies atmospheric uptake. Inland Waters. 1 (2): 125-132. DOI: 10.5268/IW-1.2.366

Barbiero, R.P., James, W.F., Barko, J.W. (1999). The effects of disturbance events on phyto plankton community structure in a small temperate reservoir. Freshwater Biology. 42: 503512.Doi: 10.1046/j.1365-2427.1999.00491.x

Bedoya-Cardona, C.M. (2017). Dinámica espacial y temporal de la estructura térmica del embalse Peñol - Guatapé. Tesis de maestría, Facultad de Minas, Departamento de Geociencias y Medio Ambiente. Programa de Posgrado. Universidad Nacional de Colombia-Sede Medellín. Medellín, Colombia.

Bernhardt, J., Elliott, J.A., Jones, I.D. (2008). Modelling the effects on phytoplankton communities of changing mixed depth and background extinction coefficient on three contrasting lakes in the English Lake District. Freshwater Biology. 53 (12): 2573-2586. Doi: 10.1111/j.13652427.2008.02083.x

Björk, S. \& Gelin, C. (1980). Limnological function and management on the El Peñol reservoir. Lund, Sweden: Institute of Limnology, University of Lund. p. 119

Bouvy, M., Nascimento, S.M., Molica, R.J.R., Ferreira, A., Huszar, V. L., Azevedo, S.M.F.O. (2003). Limnological features in Tapacurá reservoir (northeast Brazil) during a severe drought. Hydrobiology. 493 (1): 115-130. Doi: https://doi.org/10.1023/A:1025405817350

Calijuri, M.C. (1999). A comunidade fitoplanctônica em um reservatório tropical (Barra Bonita, SP). Teses de Livre-Docência, Escola de Engenharia de São Carlos. Universidad de São Paulo. São Carlos, Brasil.

Calijuri, M.C., Dos Santos, A.C.A., Jati, S. (2002). Temporal changes in the phytoplankton community structure in a tropical and eutrophic reservoir (Barra Bonita, SP-Brazil). Journal of Plankton Research. 24 (7): 617-634. Doi: 10.1093/plankt/24.7.617

Connell, J.H. (1978). Diversity in tropical rain forests and coral reefs. Science. 199 (4335): 1302-1310.

Costa, I.A.S., Azevedo, S.M.F.O., Senna, P.A.C., Bernardo, R.R., Costa, S.M, Chellappa, N.T. (2006). Occurrence of toxin-producing cyanobacteria blooms in a Brazilian semiarid reservoir. Brazilian Archives of Biology and Technology. 66 (1b): 211-219. Doi: 10.1590/ S1519-69842006000200005 
Costa, L.S., Huszar, V.L.M., Ovalle, A.R. (2009). Phytoplankton functional groups in a tropical estuary: Hydrological control and nutrient limitation. Estuarine and Coasts. 32 (3): 508-521. Doi: 10.1007/s12237-009-9142-3

Cuéllar-Márquez, W. (2009). Gestión integral de embalses en EPM. Revista Empresas Públicas de Medellín (EPM). 1: 17.

Donato, R. J. (2001). Fitoplancton de los lagos andinos del norte de Sudamérica (Colombia). Composición y factores de distribución. Bogotá, Colombia: Academia Colombiana de Ciencias Exactas, Físicas y Naturales, Colección Jorge Álvarez Lleras, (19).

Duque, S. \& Donato, J.C. (1988). Estudio del fitoplancton durante las primeras etapas de llenado del embalse de la central hidroeléctrica de Betania, Huila-Colombia. Universitas Scientiarum. 1 (2): 29-52. https://revistas.javeriana.edu.co/index.php/scientarium/article/view/5090

Edler, L. (Ed). (1979). Recommendations on methods for marine biological studies in the Baltic Sea. Phytoplankton and Chlorophyll. Stockolm, Sweden: The Baltic Marine Biologists, University of Stockholm. p. 38.

Figueredo, C.C. \& Giani, A. (2001). Seasonal variation in the diversity and species richness of phytoplankton in a tropical eutrophic reservoir. Hydrobiologia. 445 (1-3): 165-174. Doi: 10.1023/A:1017513731393

Friendly, M. (2007). 'HE plots for multivariate general linear models. Journal of Computational and Graphical Statistics. 16 (2): 421-444.

Guisande-González, C., Vaamonde-Liste, A. Barreiro-Felpeto, A. (2011). Tratamiento de datos con R, Statistica y SPSS. Madrid, Spain: Ediciones Díaz de Santos. p. 997.

Guisande-González, C., Vaamonde Liste, A., Barreiro-Felpeto, A. (2014). Paquete StatR RWizard versión Beta 1.0.

Hernández-Atilano, E., Palacio-Baena, J.A., Aguirre-Ramírez, N.J., Ramírez-Restrepo, J.J., Guisande-González, C., Duque-Escobar, S.R., Aranguren-Riaño, N.J., MogollónArismendy, M.J. (2012). Rasgos morfológicos del fitoplancton en seis sistemas leníticos de las regiones Amazónica, Andina y Caribe de Colombia. Actualidades Biológicas. 34 (96): 67-83. https://revistas.udea.edu.co/index.php/actbio/article/view/14243

Hill, M. (1973). Diversity and evenness: A unifying notation and its consequences. Ecology. 54 (2): 427-432.

Hooper, D.U., Chapin, F.S., III, Ewel, J.J., Hector, A., Inchausti, P., Lavorel, S., Lawton, J.H., Lodge, D.M., Loreau, M., Naeem, S., Schmid, B., Setälä, H., Symstad, A.J., Vandermeer, J., Wardle, D.A. (2005). Effects of biodiversity on ecosystem functioning: A consensus of current knowledge. Ecological Monographs. 75: 3-35. Doi: 10.1890/04-0922

León-López, N., Rivera-Rondón, C.A., Zapata, A., Jiménez, J., Villamil, W., Arenas, G., Rincón, C., Sánchez, T. (2012). Factors controlling phytoplankton in tropical high-mountain drinking water reservoirs. Limnetica. 31 (2): 305-322. Doi: 10.23818/limn.31.26

Lira, G.A.S.T., Araújo, E.L., Bittencourt-Oliveira, M.C., Moura, A.N. (2011). Phytoplankton abundance, dominance and coexistence in an eutrophic reservoir in the state of Pernambuco, Northeast Brazil. Anais da Academia Brasileria de Ciencias. 83 (4): 1313-1326. Doi: 10.1590/ S0001-37652011000400018

Lira, G., Moura, A.N., Vilar, M.C.P., Corediro-Araújo, M.K., Bittencourt-Oliveira, M.C. (2014). Vertical and temporal variation in phytoplankton assemblages correlated with environmental conditions in the Mundaú reservoir, semi-arid northeastern Brazil. Brazilian Journal of Biology. 74 (3 - suppl. 1): 93-102. Doi: 10.1590/1519-6984.27612

López-Muñoz, M.T. (2015). Aspectos taxonómicos y ecológicos del fitoplancton eucariótico del embalse Riogrande II (Antioquia, Colombia). Tesis de doctorado, Facultad de Ciencias Exactas y Naturales. Instituto de Biología. Programa de Posgrado. Universidad de Antioquia. Medellín, Colombia.

López-Muñoz, M.T., Ramírez-Restrepo, J.J., Palacio-Baena, J.A., Echenique, R.O., De Mattos-Bicudo, C.E., Parra-García, E.A. (2016). Biomasa del fitoplancton eucariota y su disponibilidad para la red trófica del embalse Riogrande II (Antioquia, Colombia). Revista Academia Colombiana de Ciencias Exactas, Físicas y Naturales. 40 (155): 244-253. Doi: $10.18257 /$ raccefyn. 336

Loreau, M. \& Hector. A. (2001). Partitioning selection and complementarity in biodiversity experiments. Nature. 412 (6842): 72-76. Doi: 10.1038/35083573

Mac Donagh, M.E., Casco, M.A., Claps, M.C. (2009). Plankton relationships under small water level fluctuations in a subtropical reservoir. Aquatic Ecology. 43 (2): 371-381. Doi: 10.1007/ s10452-008-9197-4 
Margalef, R. (1994). Limnology now: a paradigm of planetary problems. New York, United States: Elsevier Science. p. 553.

Marti, C., Imberger, J., Garibaldi, L., Leoni, B. (2016). Using time scales to characterize phytoplankton assemblages in a deep subalpine lake during the thermal stratification period: Lake Iseo, Italy. Water Resources Research. 52 (3): 1762-1780. Doi: 10.1002/2015WR017555

Melo, S. \& Huszar, V.L.M. (2000). Phytoplankton in an Amazonian floodplain lake (Batata Lake, Brazil): Diel variation and species strategies. Journal of Plankton Research. 22 (1): 63-76. Doi: 10.1093/plankt/22.1.63

Nascimiento-Moura, A., Dantas, E.W., Bittencourt-Oliveira, M.C. (2007). Structure of the phytoplankton in a water supply system in the State of Pernambuco-Brazil. Brazilian Archives of Biology and Technology. 50 (4): 645-654. Doi: 10.1590/S1516-89132007000400010

Ospina-Calle, L.M. (2013). Aspectos sucesionales de la comunidad fitoplanctónica en un embalse neotropical: embalse Riogrande II, Antioquia, Colombia. Trabajo de grado. Facultad de Ciencias Exactas y Naturales. Instituto de Biología. Programa de Posgrado. Universidad de Antioquia. Medellín, Colombia.

Padisák, J., Hajnal, É., Naselli-Flores, L., Martin, T.D., Nõges, P., Zohry, T. (2010). Convergence and divergence in organization of phytoplankton communities under various regimes of physical and biological control. Hydrobiologia. 639: 205-220. Doi: 10.1007/s10750-0090021-5

Palacio-Baena, J. \& Plazas, E. (1998). Algunos aspectos ecológicos de las especies ícticas más importantes en el embalse El Peñol-Guatapé. Actualidades Biológicas. 20 (68): 13-20.

Palacio-Baena, J., Herrera-Loaiza, N., López-Muñoz, M., Palacio-Betancourt, H., Rodríguez, M. (2013). Limnoecología de los embalses Riogrande II, La Fe y Porce II. En: Estudio de la problemática ambiental de tres embalses de empresas públicas de Medellín ESP para la gestión integral y adecuada del recurso hídrico. Medellín. Colombia. Universidad de Antioquia y Universidad Nacional sede Medellín.

Ramírez, J.J. (1986). Fitoplancton de red en el embalse de El Peñol. Actualidades Biológicas. 12 (56): 2-13.

Ramírez, J.J. (1989). Variación vertical del fitoplancton y parámetros fisicoquímicos en cuatro embalses del oriente antioqueño y su relación con el área, edad, altitud y tiempo de residencia media del agua. Tesis de Maestría, Facultad de Ciencias Exactas y Naturales. Instituto de Biología. Programa de Posgrado. Universidad de Antioquia. Medellín, Colombia

Ramírez, J.J. (2000). Fitoplancton de agua dulce: aspectos ecológicos, taxonómicos y sanitarios. Medellín, Colombia: Editorial Universidad de Antioquia. p. 207.

Ramírez, J.J., Bicudo, C.E. de M., Roldán, G., García, L.C. (2000). Temporal and vertical variations in phytoplankton community structure and its relation to some morphometric parameters of four Colombian reservoirs. Caldasia. 22 (1): 108-126.

Reynolds, C. (1997). Vegetation processes in the pelagic: A model for ecosystem theory. Excellence in Ecology, Book 9. Oldendorf/Luhe, Germany: Ecology Institute, Nordbunte. p. 371.

Reynolds, C.S. (2006). Ecology of phytoplankton. Nueva York, USA: Cambridge University Press. p. 524.

Reynolds, C.S., Huszar, V., Kruk, C., Naselli-Flores, L., Melo, S. (2002). Towards a functional classification of the freshwater phytoplankton. Journal of Plankton Research. 24 (5): 417 428. Doi: $10.1093 /$ plankt/24.5.417

Rodríguez-Zambrano, A.P. \& Aranguren-Riaño, N.J. (2014). Comunidad planctónica de un embalse con alta tensión ambiental: La Playa, cuenca alta del río Chicamocha (Tuta, Boyacá), Colombia. Biota Colombiana. 15 (2): 95-110. http://revistas.humboldt.org.co/index.php/ biota/article/view/323

Roldán-Pérez, G. (1978). Problemas de eutroficación en lagos y embalses colombianos. Revista de Contaminación Ambiental. 2 (3): 51-56.

Roldán-Pérez, G. (1982). Algunas consideraciones ecológicas acerca de los embalses. Revista de Contaminación Ambiental. 6: 13-20.

Roldán-Pérez, G. \& Ramírez, J.J. (2008). Fundamentos de limnología neotropical. (2da. Ed.) Medellín, Colombia: Editorial Universidad de Antioquia, Universidad Católica de Oriente y Academia Colombiana de Ciencias. p. 442.

Soares, M.C.S., Marinho, M.M., Huszar, V.L.M., Branco, C.W.C., Azevedo, S.M.F.O. (2008). The effects of water retention time and watershed features on the limnology of two tropical reservoirs in Brazil. Lakes \& Reservoirs: Research and Management. 13 (4): 257-269. Doi: 10.1111/j.1440-1770.2008.00379.x 
Soares-Vieria, P.C., Lima-Cardoso, M.M., Alves-Soares da Costa, I. (2015). Vertical and temporal dynamics of phytoplanktonic associations and the applications of index assembly in tropical semi-arid eutrophic reservoir, northeastern Brazil. Acta Limnologica Brasiliensia. 27 (1): 130-144. Doi: 10.1590/S2179-975X2614

Sokal, R. \& Rohlf, F.J. (1981). Biometry: The principles and practice of statistics in biological research. W.H. New York, United States: Freeman and Company. p. 859.

Stomp, M., Huisman, J., Mittelbach, G.G., Litchman, E., Klausmeier, C.A. (2011). Largescale biodiversity patterns in freshwater phytoplankton. Ecology. 92 (11): 2096-2107. Doi: $10.2307 / 23034942$

Thornton, K.W., Kimmel, B.L., Payne, F. E. (1990). Reservoir Limnology: Ecological perspectives. United States: John Wiley and Sons. p. 256.

Tundisi, J.G. \& Straskraba, M. (1999). Theoretical reservoir ecology and its applications. Ann Arbor: International Institute of Ecology. p. 585.

Tundisi, J.G., Matsumura-Tundisi, T., Rocha, O. (1999). Theoretical basis for reservoir management. In Jose Galizia Tundisi y M. Straškraba. Theoretical reservoir ecology and its applications. Brasilia, BraziI: International Institute of Ecology. Backhuys Publishers. p. 583.

Tundisi, J. G., Matsumura-Tundisi, T., Abe, D.S. (2008). The ecological dynamics of Barra Bonita reservoir (Tietê River, SP, Brazil) reservoir: Implications for its biodiversity. Brazilian Journal of Biology. 68 (4. Suppl.): 1079-1098. Doi: 10.1590/S1519-69842008000500015

Uribe, A. \& Roldán, G. (1975). Estudio comparativo de algunas características fisicoquímicas y biológicas del embalse El Peñol (Nare). Actualidades Biológicas. 4 (11): 2-12.

Utermöhl, H. (1958). Zur Vervollkomrnnung der quantitativen Phytoplankton-Methodik. Mitteilungen internationalen Vereinigung für theoretische und angewandte Limnologie. 9: 1-38.

Webster, I.T. (1990). Effect of wind on the distribution of phytoplankton cells in lakes. Limnology and Oceanography. 35 (5): 989-1001. Doi: 10.4319/lo.1990.35.5.0989

Wetzel, RG. \& Likens, G. E. (1991). Limnological analyses. (2 $2^{\text {da. }}$ Ed.). New York, United States: Springer-Verlag. p. 391.

Wetzel, R.G. (1993). Limnologia. (2da. Ed.). Lisboa, Portugal: Fundacao Calouste Gulbenkian. p. 919.

Wojciechowski, J., Heino, J., Bini, L.M., Padial, A.A. (2017). Temporal variation in phytoplankton beta diversity patterns and metacommunity structures across subtropical reservoirs. Freshwater Biology. 62(4): 751-766. Doi: 10.1111/fwb.12899 